\title{
Teachers' Technology Use and the Change of Their Pedagogical Beliefs in Korean Educational Context
}

\author{
Won Sug Shin ${ }^{1}$, Insook $\mathrm{Han}^{2} \&$ Insuk Kim ${ }^{3}$ \\ ${ }^{1}$ Department of Education, Korea University, Seoul, Korea \\ ${ }^{2}$ Department of Educational Technology, Hanyang Cyber University, Seoul, Korea \\ ${ }^{3}$ Korea Institute for Curriculum and Evaluation, Seoul, Korea \\ Correspondence: Insuk Kim, Korea Institute for Curriculum and Evaluation, Seoul, Korea. Tel: 82-10-9216-4777. \\ E-mail: insukkim@kice.re.kr
}

\author{
Received: April 10, 2014 Accepted: May 30, 2014 Online Published: July 27, 2014 \\ doi:10.5539/ies.v7n8p11 URL: http://dx.doi.org/10.5539/ies.v7n8p11
}

\begin{abstract}
Many researchers have attempted to identify the factors that lead teachers to use technology in the classroom. However, few studies have examined whether and how teachers' technology use change their pedagogical beliefs. Therefore, this study investigates how teacher-related factors influence teachers' use of technology, and how changes subsequently occur in their pedagogical beliefs when they incorporate technology into their teaching practice. The study participants were 659 in-service teachers from elementary schools in South Korea. We employed structural equation modeling to determine the relationship between the intrinsic and extrinsic factors influencing teachers' use of technology, as well as changes in their pedagogical beliefs. The results showed that an intrinsic factor, namely teachers' attitude toward technology, mostly drives their use of technology in practice, and triggers changes in their beliefs. In addition, extrinsic factors such as the pressure to use technology and administrative support can affect teachers' use of technology and changes in their beliefs. Finally, this study provides implications for teachers, school administrators, and policymakers that contribute to the discussion on technology integration in the classroom.
\end{abstract}

Keywords: teacher beliefs, teacher's technology use, technology integration

\section{Introduction}

Since information and communications technology (ICT) entered classrooms in the 1980s, it has triggered changes in teaching and learning activities. Teachers' use of technology in the classroom has increased dramatically in the last two decades. However, technology use in the classroom is not widespread or consistent (O’Dwyer, Russell, \& Bebell, 2005; Park \& Ertmer, 2007; Levin \& Wadmany, 2008). Thus, previous research has focused on examining the factors influencing teachers' technology use, and many of them have shown that teachers' constructivist pedagogical beliefs positively influence their instructional practice and computer use in the classroom (Ertmer, 2005; Levin \& Wadmany, 2006; Ertmer \& Ottenbreit-Leftwich, 2010; Liu, 2011). In contrast, other studies have presented an inconsistency between teachers' beliefs and their technology use. According to them, teachers simply use new technology to continue what they have always done, although they often claim to have changed their teaching practice. For example, teachers who describe themselves as having constructivist philosophies implement technology in ways that might best be described as a mixed or traditional approach (Ertmer, 2005; Petko, 2012). Liu (2011) also indicated an inconsistency between teachers' beliefs and teaching activities, showing that approximately $72 \%$ of teachers who held learner-centered beliefs in the study implemented lecture-based teaching. As Ertmer (2005) indicated, this inconsistency is due to most teachers having a limited understanding of and experience with how technology can and should be integrated into various instructional practices. Therefore, the teachers who responded that they had learner-centered beliefs may have lacked an understanding of technology-integrated lessons, resulting in a failure to implement constructivist-teaching activities in their classrooms. However, once teachers experience technological innovation achieving its goal, their pedagogical beliefs can shift from a more teacher-centered to a more student-centered instruction, and most educators without successful experience underwent a superficial change with the integration of new technology (Miller, 2008). This implies that technology can act as a lever to an extent for the reorientation of teachers' beliefs and practices, despite technology itself not being a driving force in 
teachers' thinking and practice (Hennessy, Ruthven, \& Brindley, 2005).

Despite there exists theoretical discussions addressing the effect of technology use on the change of teacher's pedagogical beliefs, few empirical studies have examined whether the use of technology triggers a change in teacher's beliefs. This study, therefore, investigates whether the use of technology makes teachers adjust their beliefs in teaching along with other factors having been proven influential in teachers' use of technology.

\section{Theoretical Background}

This study considers five factors influencing teachers' use of technology and change in teacher's pedagogical beliefs. Attitude toward technology has been considered as a typical factor in numerous studies. Especially, in Korean educational context, pressure to use technology and ICT policy are big issues in technology integration by teachers. Also, supports from school and school administrators have been reported as important when teachers decide to use technology and change their beliefs. Therefore, we selected these variables and incorporated into our research model.

\subsection{Factors Associated with the Use of Technology}

\subsubsection{Attitude toward Technology}

A person's attitude toward computers and technology has been considered a typical intrinsic factor as well as one of the most researched factors. Previous studies have also found it to be a major predictor of the use of technology in instructional settings. Attitudes toward technology in education influence the use of technology, and can lead to changes in teachers' activities in the classroom. Sang et al. (2011) supported the notion that if teachers have favorable attitudes toward technology, they are likely to integrate it into their teaching.

Certain researchers (Becker, 1999; Zhao \& Frank, 2003)have found that teachers who place a more positive value on computers tend to use computers more frequently in their instruction; that is, beliefs on the value of computers greatly enhance teachers' perceptions of the effectiveness of computers for teaching and learning. Therefore, the perceived relevancy of technology in the classroom can have a considerable effect on its subsequent use in the classroom (Park \& Ertmer, 2007). In addition, several studies(van Braak, 2001; Paraskeva, Bouta, \& Papagianni, 2008; Teo, 2011)have indicated that the likelihood of teachers using technology and the success of technology use are substantially related to teachers' attitudes toward technology.

\subsubsection{Pressure to Use Technology}

Studies have indicated that one of the strongest factors influencing teachers' use of technology is the perceived pressure to use it (O'Dwyer, Russell, \& Bebell, 2004). As technologies develop, teachers face increasing pressure to integrate innovations into their pedagogical practice. The reviewed literature suggests that when teachers feel pressured to use technology, they are more likely to use it to deliver instruction, to have their students use it during class time, to create materials using technology, and, to a lesser extent, to use technology for class preparation (O'Dwyer et al., 2004, Russell et al., 2003). In addition, teachers who perceive pressure from their colleagues are more likely to use computers (Zhao \& Frank, 2003).

\subsubsection{Administrative Support}

Other studies have focused on administrative support in teachers' use of technology, because such support is critical for encouraging the adoption of instructional technology (Sandholtz, Ringstaff, \& Dwyer, 1997; Zhao et al., 2002; Inan \& Lowther, 2010). These studies have suggested that administrative support is important in influencing teachers' decision to integrate technology into their teaching practice (Sandholtz et al., 1997; Hsu \& Kuan, 2013). For example, the level of institutional support plays a substantial role in determining the level of technology implementation in the classroom (Ertmer \& Ottenbreit-Leftwich, 2010), and technology use depends substantially on the vision of the school's administration (Zhao et al., 2002).

\subsubsection{School Support}

School support includes technology facilities, technicians, maintenance, infrastructure, and administrative and financial support. The fundamental support provided by schools involves the technological facilities provided to teachers: computers, software, technical infrastructure (e.g., an Internet connection), and peripherals, including projectors, printers, and digital and video cameras. Many studies have indicated that poor school support can be an obstacle toward instituting more extensive technology-integrated practice (Becker, 1999; Ertmer, 2005), and that school technology support has a significant effect on teachers' effective integration of technology into the classroom (Inan \& Lowther, 2010). Becker (1999)identified school support for technology integration as a positive factor that encourages teachers to use technology. Sandholtz et al. (1997) reported that school support is important in encouraging teachers to change to more technology-integrated teaching practices. They have 
suggested that quality technology support, such as personalized technical support for classroom teachers, enhances teachers' use of technology in the classroom (Sandholtz et al., 1997).

\subsubsection{ICT Policy}

Government ICT policy is considered an external input that influences teachers' integration of technology into the classroom. Whereas a government's ICT policy may directly affect instructional activities, its influence may also be indirectly found in a school's curriculum and support, as well as technological infrastructure. Thus, ICT policy includes the perceived effectiveness of technology to enhance teaching and learning, administrative and school support, and technological infrastructure (Wong \& Li, 2008). Sang et al. (2011) indicated that the successful integration of technology in schools requires an appropriate school technology plan, and that when the school emphasizes and supports technology integration into teaching, teachers are more willing to adopt technology.

According to Fullan (2001), ICT policy is the most predominant and significant external factor affecting sustainability because government policies and plans typically provide special funding for hardware, software, and network infrastructure in schools, as well as teachers' professional development. Moreover, ICT policy provides an added rationale to support and give priority to local ICT innovation (Owston, 2007). The South Korean Ministry of Education and local education authorities, for example, have encouraged teachers to use technology, asserting that it enhances instructional objectives. Baek et al. (2008) indicated that teachers decide to use technology primarily to meet the requirements of external policies and needs, rather than because of their belief in its effectiveness in their classrooms.

\subsection{Research Questions}

The purpose of this study was to examine how teachers' technology use affects their pedagogical beliefs. For this purpose, we investigated the relationship between technology use and teachers' pedagogical beliefs along with factors influencing teachers' technology use and beliefs. Our research questions are as follows: (a) Do teachers' use of technology influence their pedagogical beliefs? (b) Do teachers' attitudes toward technology, pressure to use technology, administrative support, and ICT policy influence their technology use? And (c) Do teachers' attitudes toward technology, pressure to use technology, administrative support, and ICT policy affect their pedagogical beliefs?

\section{Method}

\subsection{Participants}

Participants were all in-service teachers from 31 elementary schools in South Korea. A total of 661 in-service teachers participated in this study. There were $537(81.2 \%)$ females and the overall mean teaching experience was 13.3 years. All participants were asked to complete a survey. The participants were instructed to give their genuine responses and warranted that their responses would be kept confidential at all time. After excluding two incomplete surveys, we used 659 surveys for the final analysis.

\subsection{Instrument}

To measure the predictor that influenced teachers' technology use for instructional activities, we reused several existing surveys after making revisions to accommodate the educational context of South Korea; item wordings were changed for application to the local context. All survey items used a 5-point Likert scale ranging from 1 (strongly disagree) to 5 (strongly agree), and were translated into South Korean for implementation using back-translation, to develop a Korean version. Finally, four instructional technologists and Korean-English bilingual researchers assessed all of the items for language translation and grade-level appropriateness. In addition, two in-service elementary school teachers reviewed the items to confirm their applicability to South Korean teachers.

Data were collected on teachers' perception of factors influencing technology use, "attitude toward computers in education" (van Braak, 2001) and "pressure to use technology" (O’Dwyer et al., 2005), to measure teacher's perceived pressure from external forces. The Perceived Administrative Support of Technology Scales (Petherbridge, 2007) were adapted to assess administrative support, and the items for assessing school support were reconstructed based on Quality Technology Support (Jun, 2004). ICT policy was measured by combining the revised existing surveys "the District success in implementing the technology program" (O'Dwyer et al., 2005) and the Government ICT policy scale (Wong \& $\mathrm{Li}$, 2008) to measure teachers' perception regarding the degree of successful ICT policy implementation.

The change in teacher beliefs, including four items selected using the Constructivist Teaching Beliefs Scale, was 
adapted from Woolley, Benjamin, and Woolley (2004), which examines whether teachers' beliefs on instructional activities have changed from traditionalist to constructivist-in other words, from teacher- to student-centered - after they began using technology in their instructional activities.

The survey was designed to be anonymous, enabling the collection of more honest responses from the study participants.

\subsection{Data Analyses}

The purpose of this study was to investigate the relationships between teachers' attitude toward technology, pressure to use technology, administrative support, school support, and ICT policy and their use of technology in classroom, as well as changes in teachers' pedagogical beliefs. We employed structural equation modeling (SEM), which tests how well the proposed model fits the data, and includes a measurement model and a structural model. The measurement model relates latent variables (factors) to their indicators (items), and the structural model displays the interrelationships among the factors and items in the model.

We also examined the descriptive statistics, reliability, and correlation. For SEM, the measurement model and the structural model were simultaneously estimated running maximum likelihood estimation (MLE) through an SEM program. LISREL 8.54. MLE is among the most popular and robust methods for SEM application (Hoyle, 1995).

\section{Results}

\subsection{Descriptive Statistics and Reliability}

The descriptive statistics of the items shows that the means range from 2.55 to 3.70. No item showed a skew or kurtosis value greater than the cutoff of $|2|$, as recommended by Kline (2005), thereby indicating univariate normality in the items.

We employed Cronbach's alpha, one of the most widely used measures for evaluating reliability. As shown in Table 1 , the reliability coefficients for the scales range from 0.802 to 0.922 , indicating good internal consistency regarding the items on the scale. George and Mallery (2003, p. 231) provided the following rules: “_>.9-Excellent,_>.8-Good,_>.7-Acceptable,_> .6-Questionable,_> .5-Poor, and _ $<.5$-Unacceptable.”

Table 1 . Reliability of the scale

\begin{tabular}{|c|c|c|c|}
\hline Factor & $\begin{array}{l}\text { No. of } \\
\text { Items }\end{array}$ & Example item & Alpha \\
\hline $\begin{array}{l}\text { Technology Use } \\
\text { (TECH USE) }\end{array}$ & 7 & Search, revise, and/or develop learning materials & 0.802 \\
\hline $\begin{array}{l}\text { Attitude toward } \\
\text { Technology } \\
\text { (TECH) }\end{array}$ & 6 & The computer increases the students' level of creativity & 0.814 \\
\hline $\begin{array}{l}\text { Pressure to Use } \\
\text { Technology } \\
\text { (PRESS) }\end{array}$ & 3 & $\begin{array}{c}\text { Do you feel pressured to use technology in order to teach } \\
\text { students? }\end{array}$ & 0.869 \\
\hline $\begin{array}{c}\text { Administrative Support } \\
\text { (ADMIN) }\end{array}$ & 5 & Administrators provide administrative support actively & 0.922 \\
\hline $\begin{array}{l}\text { School Support } \\
\text { (SUPPORT) }\end{array}$ & 5 & Well-maintained technological facilities & 0.869 \\
\hline $\begin{array}{l}\text { ICT Policy } \\
\text { (POLICY) }\end{array}$ & 5 & Compilation and execution of the ICT budget & 0.862 \\
\hline $\begin{array}{c}\text { Change in Teachers' } \\
\text { Beliefs } \\
\text { (CHANGE) }\end{array}$ & 4 & $\begin{array}{l}\text { Since the introduction of ICT, I have interacted with students } \\
\text { more frequently }\end{array}$ & 0.833 \\
\hline
\end{tabular}




\subsection{Correlation}

To understand the relationships between the variables, we performed Pearson correlation analysis by using the sums of the variables. Table 2 shows the correlations among variables examined in this study. The correlation coefficients range from 0.141 to 0.558 , and are statistically significant at $\alpha<.01$, indicating positive relationships between the variables. While a few correlations were low (less than .2), some of them were of moderate magnitude (more than .2 and less than .6), indicating that there were to some degree correlations among variables. Specifically, the correlation between SUPPORT and TECH USE was the lowest $(r=.141)$ and the correlation between SUPPORT and ADMIN was the highest $(\mathrm{r}=.558)$.

Table 2. Correlations of the variables

\begin{tabular}{llllllll}
\hline & TECH USE & TECH & PRESS & ADMIN & SUPPORT & POLICY & CHANGE \\
\hline TECH USE & 1 & & & & & & \\
TECH $^{\mathrm{a}}$ & 0.406 & 1 & & & & & \\
PRESS $^{\mathrm{b}}$ & 0.254 & 0.337 & 1 & & & & \\
ADMIN $^{\mathrm{c}}$ & 0.275 & 0.339 & 0.273 & 1 & & & \\
SUPPORT $^{\mathrm{d}}$ & $\mathbf{0 . 1 4 1}$ & $\mathbf{0 . 2 2 5}$ & 0.192 & 0.558 & 1 & & \\
POLICY $^{\mathrm{e}}$ & 0.182 & 0.294 & 0.309 & 0.500 & 0.544 & 1 & \\
CHANGE $^{\mathrm{f}}$ & 0.340 & 0.550 & 0.358 & 0.409 & 0.296 & 0.393 & 1
\end{tabular}

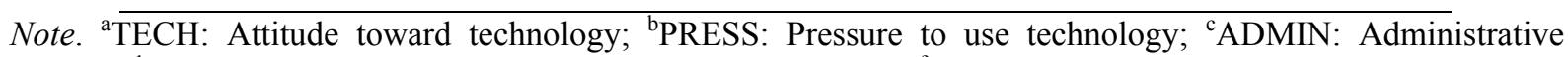
support; ${ }^{\mathrm{d}}$ SUPPORT: School Support; ${ }^{\mathrm{e} P O L I C Y}$ : ICT policy; and ${ }^{\mathrm{f}} \mathrm{CHANGE}$ : Change in teachers' Beliefs

\subsection{The Measurement Model}

Before interpreting the structural model, we first had to ensure that the measurement model fits. To test the measurement model (see Figure 1), we used confirmatory factor analysis (CFA), because the extent to which a factor is accurately defined depends on how strongly related the items are.

All of the factor loadings and the significance of the $t$ values of the 35 items regarding the seven factors specify the relationships of the items to their posited underlying factors. 


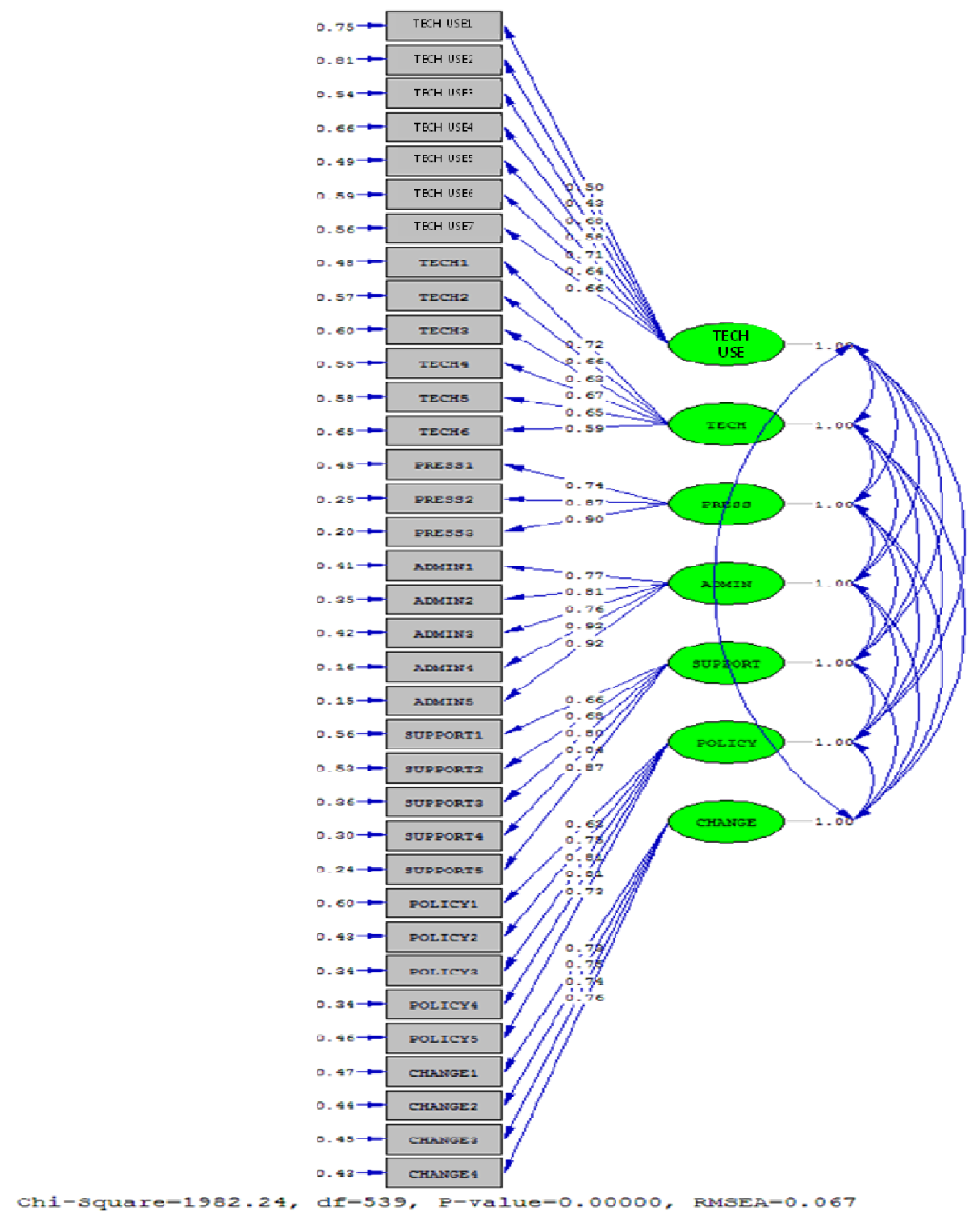

Figure 1. The measurement model

Note. Squares: observed variables, items; circles: latent variables, factors; single arrowhead: causal effect of a factor on an indicator; a curved line with two arrowheads: correlations between factors

Researchers can use numerous goodness-of-fit indicators to assess a model. For example, the chi-square value is one of many measures of how well a factor model fits the data. However, the chi-square test is overly sensitive to the sample size. The root mean square residual (RMSR), which is the most sensitive to simple model misspecification, depends on the size of the element in the sample correlation or covariance matrix. Hu and Bentler (1998) recommended a cutoff of 0.08 or less. The comparative fit index (CFI) is used to compare the superiority of the target model for a fit compared to the baseline model. If the target and baseline models have an equal degree of misfit, the CFI equals 0, whereas it approaches 1 if the target model is a better fit than the baseline model. The root mean square error of approximation (RMSEA) is a standardized measure of the lack of fit of the population data to the model. Values of approximately .05 are generally considered to indicate a close fit, and values up to approximately .08 are considered reasonable (Kline, 2005).

The fit indices of the measurement model revealed that $\chi^{2}=1982.24$, $\mathrm{df}=539$; $\mathrm{SRMR}=0.053 ; \mathrm{CFI}=0.96$; and RMSEA $=0.067$. These values are indicative of a good model fit to the data, according to Kline (2005).

\subsection{The Structural Model}

The test of the structural model includes assessing the statistical significance of the path coefficients by factor. 
Table 3 and Figure 2 show the analysis of the structural model. The final model does not include "SUPPORT," because its correlation coefficients to TECH USE, TECH, and PRESS are lower than other variables, and the correlation coefficient to ADMIN is high. After "SUPPORT" was removed from the model, the fit of model was improved. We established the statistical significance of the path coefficients by examining the $t$ statistics, which is greater than $|2|$. Seven path coefficients were statistically significant.

Table 3. Analysis of the structural model

\begin{tabular}{cccccc}
\hline & Path & & Coefficient & Standard Error & $t$ statistics \\
\hline TECH $^{\mathrm{a}}$ & $\rightarrow$ & TECH USE & 0.43 & 0.063 & 6.83 \\
PRESS $^{\mathrm{b}}$ & $\rightarrow$ & TECH USE & 0.13 & 0.050 & 2.60 \\
ADMIN $^{\mathrm{c}}$ & $\rightarrow$ & TECH USE & 0.15 & 0.054 & 2.75 \\
POLICY $^{\mathrm{d}}$ & $\rightarrow$ & TECH USE & -0.04 & 0.055 & -0.67 \\
TECH USE $\rightarrow$ & CHANGE & 0.06 & 0.050 & 1.25 \\
TECH & $\rightarrow$ & CHANGE & 0.49 & 0.056 & 8.72 \\
PRESS & $\rightarrow$ & CHANGE & 0.12 & 0.043 & 2.72 \\
ADMIN & $\rightarrow$ & CHANGE & 0.11 & 0.046 & 2.48 \\
POLICY & $\rightarrow$ & CHANGE & 0.19 & 0.048 & 4.00
\end{tabular}

Note. ${ }^{\mathrm{a}}$ TECH: Attitude toward technology; ${ }^{\mathrm{b}} \mathrm{PRESS}$ : Pressure to use technology; ${ }^{\mathrm{c}}$ ADMIN: Administrative support; ${ }^{\mathrm{P} O L I C Y}$ : ICT policy

The fit indices of the structural models are $\chi^{2}=1539.90, \mathrm{df}=390 ; \mathrm{SRMR}=0.056 ; \mathrm{CFI}=0.95 ;$ and RMSEA $=$ 0.071. Most researchers regard these values as indicative of a good model fit to the data (Hu \& Bentler, 1999; Kline, 2005).

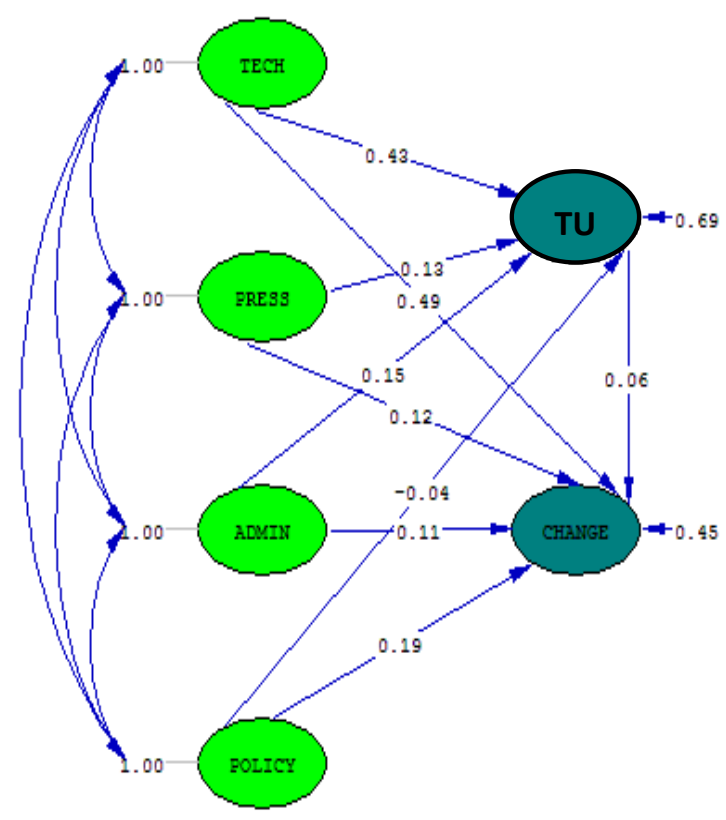

Figure 2. Path coefficient of the structural model

Note. Single arrowhead: direct effects of one factor on another 
As shown in Figure 2, the attitude toward technology has a positive impact on both teachers' use of technology in teaching and changes in their beliefs. This finding suggests that teachers' use of technology and changes in their beliefs are mostly driven by an intrinsic factor namely their attitude toward technology.

In addition, the pressure to use technology and administrative support has an effect on both teachers' use of technology and changes in their beliefs. This finding indicates that extrinsic factors may contribute to teachers' use of technology and changes in their beliefs.

ICT policy, however, does not have an effect on teachers' use of technology in teaching, but triggers changes in their beliefs. This means that ICT policy does not make teachers use technology, but it triggers a change in their beliefs.

Lastly, teachers' use of technology in teaching does not have an effect on changes to their practice. This means that current technology use does not seem to be related to changes in teachers' beliefs.

\section{Discussion}

Unlike other studies that examine the outcomes of technology use in classrooms, this study explored teachers' technology use as well as the changes in teachers' beliefs influenced by technology use. Specifically, this study investigated whether the intrinsic (attitude toward technology and pressure to use technology) and extrinsic factors (administrative support and ICT policy) affecting teachers influence their use of technology and change their pedagogical beliefs. Overall, evidence supporting the results of extant research exists, indicating that teachers' personalities and their environment affect their use of technology in the classroom. In addition, we partially confirmed the relationships between teacher-related factors and teachers' use of ICT and changes in their beliefs, as reflected in the structural model.

First, we examined whether teachers' use of technology triggers changes in their pedagogical beliefs. Unlike our hypothesis, the results of this study indicate that teachers' use of technology does not directly induce changes in their beliefs. This finding implies that teachers might have used technology in ways that have changed their practice only superficially but did not fundamentally challenge their underlying beliefs, and therefore, they did not necessarily approach their students in a constructivist manner. Previous studies have also addressed this issue by reporting that teachers had decided to use technology for physical relief, rather than because of a belief in the effectiveness of technology in their classroom (Baek et al., 2008). In addition, most teachers experienced a superficial change in the use of new technology, even when using them became a regular teaching activity (Miller, 2008). Because teachers' pedagogical beliefs can shift from a more teacher-centered to a more student-centered instruction when they experience a technological innovation (Miller, 2008), we can consider teachers' use of technology in this study as low-level technology use, regardless of their own perception. This low-level technology use is usually due to increased demands of extrinsic factors, such as policy reinforcement and societal pressures, resulting in superficial changes in content, objectives, and the structure of teaching practice, as well as the sustenance of a teacher-centered approach (Fullan, 2007; Shin, 2014). Therefore, in order to elicit technological innovation from teachers that can potentially change their beliefs, many studies have suggested that professional development instigates changes in intrinsic factors influencing technology use, rather than external factors. For instance, Ertmer and Ottenbreit-Leftwich (2010) indicated that teachers need sustained support to challenge their professional beliefs regarding practice with the aid of technology. In addition, Inan and Lowther (2010) emphasized the importance of quality in-service professional development that can help teachers recognize the effectiveness of technology-integrated lessons, and eventually change their pedagogical beliefs. Through professional development, teachers can also gain confidence and comfort in using technology, and gradually stress a more constructivist, learner-centered approach by effectively integrating technology into their practice (Matzen \& Edmunds, 2007).

Second, this study examined whether teachers' attitude toward technology, pressure to use technology, administrative support, and ICT policy influence their use of technology and change their pedagogical beliefs. Regarding attitude toward technology, the result of this study shows that an intrinsic factor significantly influences both teachers' use of technology and changes in their pedagogical beliefs(TECH $\rightarrow$ TECH USE: 0.43, TECH $\rightarrow$ CHANGE: 0.49, See Table 3). This result implies that teachers' attitude is still the most important factor related to the integration of technology into teaching. This finding confirms the results of previous studies that have shown that the likelihood of teacher integrating technology, in addition to its effective use and implementation, are closely related to users' attitudes toward computers or technology (van Braak, 2001; Paraskeva et al., 2008). In other words, positive attitudes toward the value of technology greatly enhance teachers' use of technology for instruction, and triggers changes in their instructional approach with constructivist methodologies. Thus, the perceived relevancy of technology in the classroom can have a 
significant effect on its subsequent use in instruction (Park \& Ertmer, 2007).

The pressure to use technology and administrative support are extrinsic factors that also influence teachers' technology use and changes in their beliefs(PRESS $\rightarrow$ TECH USE: 0.13, PRESS $\rightarrow$ CHANGE: 0.12, ADMIN $\rightarrow$ TECH USE: 0.15 , ADMIN $\rightarrow$ CHANGE: 0.11, See Table 3). This finding is in accordance with those of previous studies. In addition, the finding supports the notion that the pressure to use technology is positively associated with teachers' active use of technology (Russell et al., 2003; O’Dwyer et al., 2004, 2005; Ertmer \& Ottenbreit-Leftwich, 2010), and that administrative support has a significant influence on teachers' technology use and changes in their pedagogical beliefs (Sandholtz et al., 1997; Zhao et al., 2002; Sang et al., 2010).As mentioned, as technology develops, teachers face increasing pressure to integrate technology into their teaching practice. Researchers (e.g., O'Dwyer et al., 2004; Baek et al., 2008) have found that when teachers feel pressured to use technology, they are more likely to do so. Therefore, it is important for teachers to know how to cope effectively with such pressure, because teachers are responsible for the effective integration of technology in classrooms (Zhao et al., 2002). In addition, Sang et al. (2010) indicated the importance of administrative support for technological integration. They argued that classroom technology use depends directly on teachers' computer motivation as well as supportive technology use; teachers' perceptions regarding a school's technological support and its management by administrators significantly influence teachers' technological integration. Therefore, the pressure to use technology and administrative support for technological integration into teaching seemingly directly affect teachers' technology use and changes in their beliefs.

This study's results indicate that ICT policy does not have a significant effect on teachers' technology use in the classroom, but instead changes their pedagogical beliefs. This means that ICT policy itself does not force teachers to use technology directly, but it ultimately changes their beliefs. In South Korea, where this study was conducted, ICT policy has required teachers to use technology in classrooms since 2001; the national curriculum requires that computers be used during instruction for $10 \%$ or more of the time spent on every subject (Kim \& Santiago, 2005; So, Choi, Lim, \& Xiong, 2012). Thus, the perception on current ICT policy seemingly does not affect teachers' ICT use in practice, because, over a decade, teachers are already using technology in their daily teaching activities. When considering the positive influences on teachers' pedagogical changes, however, ICT policy seems to eventually change teachers' beliefs. Because ICT policy has influenced curricula, school support, and the technological infrastructure (Wong \& Li, 2008) continuously for more than a decade, it might have triggered changes in teachers' beliefs. Therefore, ICT policy apparently does not increase teachers' use of technology further because most teachers are already using it, but instead acts as a catalyst for changes to teachers' pedagogical approaches and beliefs through technology.

\section{Conclusion}

This study has several implications for teachers, school administrators, and policymakers. Previous studies have argued that teachers' integration of technology into teaching results in changes to their practice from teacher- to student-centered approaches. As research has indicated, school administrators and educational policymakers have invested in technology-related facilities and curricula. Teachers' use of technology in their teaching activities, however, has yet to meet the expectations of educational stakeholders.

Our results suggest that teachers' use of technology in practice does not necessarily guarantee a change in their beliefs in a constructivist manner, as Ertmer (2005) indicated. Teacher thinking and teacher change, and how they relate to a teacher's beliefs is reciprocal (Levin \& Wadmany, 2005; Ertmer \& Ottenbreit-Leftwich, 2010; Liu, 2011). Teachers' knowledge and beliefs influence and support their classroom practice; in turn, the classroom experience shapes the teachers' educational beliefs and knowledge. Changes to educational beliefs (on technology) occur gradually. Teachers' beliefs regarding learning processes and encouraging self-regulated learning, for example, are more difficult to change than the learning process, including knowledge transformation (Levin \& Wadmany, 2005).

Technological integration is a complex process influenced by both teachers' characteristics and their perception of the school environment (Inan \& Lowther, 2010; Kim et al., 2013). To date, researchers have focused mainly on teachers' intrinsic factors, such as their attitude toward technology, rather than extrinsic factors, such as ICT policy and support. As indicated in this study, we must increase our attention to teachers' environments in order to induce fundamental changes to their teaching behavior and provide relevant support.

Although this study has significant implications for technological integration into practice, it also has limitations. First, this study excluded other variables that may significantly affect changes in teachers' practice. Therefore, the SEM results could possibly have indicated more significance if other variables, such as technological competence and school culture, had been included. Second, our data analysis was based on self-reported 
information, which can be subject to response bias. Third, although this study produced significant results and implications for teachers' use of technology, the findings may not be generalized to other countries because of their different educational contexts.

\section{References}

Baek, Y. G., Jong, J., \& Kim, B. (2008). What makes teachers use technology in the classroom? Exploring the factors affecting facilitation of technology with a Korean sample. Computers \& Education, 50(8), 224-234. http://dx.doi.org/10.1016/j.compedu.2006.05.002

Becker, H. J. (1999). Internet use by teachers: Conditions of professional use and teacher-directed student use (Vol. 1). Center for Research on Information Technology and Organizations, the University of California, Irvine and the University of Minnesota.

Ertmer, P. A. (2005). Teacher pedagogical beliefs: The final frontier in our quest for technology integration? Educational Technology Research and Development, 53(4), 25-40. http://dx.doi.org/10.1007/BF02504683

Ertmer, P. A., \& Ottenbreit-Leftwich, A. T. (2010). Teacher technology change: How knowledge, confidence, beliefs, and culture intersect. Journal of Research on Technology in Education, 42(3), 255-284.

Fullan, M. (2001). Leading in a culture of change. San Francisco, CA: Jossey-Bass.

Fullan, M. (2007). The new meaning of organizational change (4th ed.). New York: Teachers College Press.

George, D., \& Mallery, P. (2003). SPSS for Windows step by step: A simple guide and reference, 11.0 update (4th ed.). Boston: Allyn \& Bacon.

Hennessy, S., Ruthven, K., \& Brindley, S. (2005). Teacher perspectives on integrating ICT into subject teaching: Commitment, constraints, caution, and change. Journal of Curriculum Studies, 37(2), 155-192. http://dx.doi.org/10.1080/0022027032000276961

Hoyle, R. H. (1995). The structural equation modeling approach: Basic concepts and fundamental issues. In R. H. Hoyle (Ed.), Structural equation modeling: Concepts, issues, and applications (pp. 158-176). Thousand Oaks, CA: Sage.

Hu, L. T., \& Bentler, P. M. (1998). Fit indices in covariance structure modeling: Sensitivity to underparameterized model misspecification. Psychological Methods, 3, 424-453. http://dx.doi.org/10.1037/1082-989X.3.4.424

Hu, L.-T., \& Bentler, P. M. (1999). Cutoff criteria for fit indices in covariance structure analysis: Conventional criteria versus new alternatives. Structural Equation Modeling, 6, 1-55. http://dx.doi.org/10.1080/10705519909540118

Inan, F. A., \& Lowther, D. L. (2010). Factors affecting technology integration in K-12 classrooms: A path model. Educational Technology Research and Development, 58(2), 137-154. http://dx.doi.org/10.1007/s11423-009-9132-y

Jun, M.-K. (2004). The influence of quality technology support on teachers' effective technology integration in relation to the maturity of a school work environment as a professional learning community (Unpublished doctoral dissertation). University of Iowa.

Kim, C. J., \& Santiago, R. (2005). Construction of e-learning environments in Korea. Educational Technology Research and Development, 53(4), 108-115. http://dx.doi.org/10.1007/BF02504690

Kim, C., Kim, M. K., Lee, C., Spector, J. M., \& DeMeester, K. (2013). Teacher beliefs and technology integration. Teaching and Teacher Education, 29, 76-85. http://dx.doi.org/10.1016/j.tate.2012.08.005

Kline, R. B. (2005). Principles and practise of structural equation modeling. New York: Guilford Press.

Levin, T., \& Wadmany, R. (2005). Changes in educational beliefs and classroom practices of teachers and students in rich technology-based classrooms. Technology, Pedagogy and Education, 14(3), 281-307. http://dx.doi.org/10.1080/14759390500200208

Levin, T., \& Wadmany, R. (2008). Teachers' views on factors affecting effective integration of information technology in the classroom: Developmental scenery. Journal of Technology and Teacher Education, 16(2), 233-264.

Liu, S. (2011). Factors related to pedagogical beliefs of teachers and technology integration. Computers \& Education, 56, 1012-1022. http://dx.doi.org/10.1016/j.compedu.2010.12.001 
Matzen, N. J., \& Edmunds, J. A. (2007). Technology as a catalyst for change: The role of professional development. Journal of Research on Technology in Education, 39(4), 417-430.

Miller, R. T. (2008). Laptop educators: Identifying laptop use and pedagogical change (Unpublished doctoral dissertation). The University of Utah, Utah, United States.

O’Dwyer, L. M., Russell, M., \& Bebell, D. (2005). Identifying teacher, school, and district characteristics associated with middle and high school teachers' use of technology: A multilevel perspective. Journal of Educational Computing Research, 33(4), 369-393. http://dx.doi.org/10.2190/4BVW-5NDJ-L2G3-EAND

O’Dwyer, L., Russell, M., \& Bebell, D. (2004). Elementary teachers' use of technology: Characteristics of teachers, schools and districts associated with technology use. Boston, MA: Technology and Assessment Study Collaborative, Boston College. Retrieved July 25, 2013, from http://www.bc.edu/research/intasc/studies/USEIT/pdf/USEIT_r13.pdf

Owston, R. (2007). Contextual factors that sustain innovative pedagogical practice using technology: An international study. Journal of Educational Change, 8, 61-77. http://dx.doi.org/10.1007/s10833-006-9006-6

Paraskeva, F., Bouta, H., \& Papagianni, A. (2008). Individual characteristics and computer self-efficacy in secondary education teachers to integrate technology in educational practice. Computers \& Education, 50(3), 1084-1091. http://dx.doi.org/10.1016/j.compedu.2006.10.006

Park, S. H., \& Ertmer, P. A. (2007). Impact of problem-based learning (PBL) on teachers' beliefs regarding technology use. Journal of Research on Technology in Education, 40(2), 247-267.

Petherbridge, D. T. (2007). A concerns-based approach to the adoption of web-based learning management systems(Unpublished doctoral dissertation). North Carolina State University.

Petko, D. (2012). Teachers' pedagogical beliefs and their use of digital media in classrooms: Sharpening the focus of the 'will, skill, tool' model and integrating teachers' constructivist orientations. Computers \& Education, 58(4), 1351-1359. http://dx.doi.org/10.1016/j.compedu.2011.12.013

Rogers, D. L. (2000). A paradigm shift: Technology integration for higher education in the new millennium. Educational Technology Review, 13, 19-33.

Russell, M., Bebell, D., O’Dwyer, L., \& O'Connor, K. (2003). Examining teacher technology use: Implications for preservice and inservice teacher preparation. Journal of Teacher Education, 54(4), 297-310. http://dx.doi.org/10.1177/0022487103255985

Sandholtz, J. H., Ringstaff, C., \& Dwyer, D. C. (1997). Teaching with technology: Creating student-centered classrooms. New York: Teachers College Press.

Sang, G., Valcke, M., van Braak, J., Tondeur, J., \& Zhu, C. (2011). Predicting ICT integration into classroom teaching in Chinese primary schools: Exploring the complex interplay of teacher-related variables. Journal of Computer Assisted Learning, 27(2), 160-172. http://dx.doi.org/10.1111/j.1365-2729.2010.00383.x

Shin, W. S. (2014). Teachers' use of technology and its influencing factors in Korean elementary schools. Technology, Pedagogy and Education (ahead-of-print), 1-16. http://dx.doi.org/10.1080/1475939X.2014.915229

So, H.-J., Choi, H., Lim, W. Y., \& Xiong, Y. (2012). Little experience with ICT: Are they really the Net

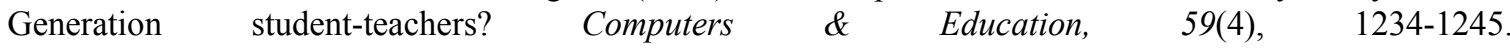
http://dx.doi.org/10.1016/j.compedu.2012.05.008

Teo, T. (2011). Factors influencing teachers' intention to use technology: Model development and test. Computers \& Education, 57, 2432-2440. http://dx.doi.org/10.1016/j.compedu.2011.06.008

Van Braak, J. (2001). Individual characteristics influencing teachers' class use of computers. Journal of Educational Computing Research, 25(2), 141-157.http://dx.doi.org/10.2190/81YV-CGMU-5HPM-04EG

Wong, E. M. L., \& Li, S. C. (2008). Framing ICT implementation in a context of educational change: A multilevel analysis. School Effectiveness and School Improvement, 19(1), 99-120. http://dx.doi.org/10.1080/09243450801896809

Woolley, S. L., Benjamin, W. J. J., \& Woolley, A. W. (2004). Construct validity of a self-report measure of teacher beliefs related to constructivist and traditional approaches to teaching and learning. Educational and Psychological Measurement, 64(2), 319-331. http://dx.doi.org/10.1177/0013164403261189

Zhao, Y., \& Frank, K. A. (2003). Factors affecting technology uses in schools: An ecological perspective. 
American Educational Research Journal, 40(4), 807-840. http://dx.doi.org/10.3102/00028312040004807

Zhao, Y., Pugh, K., Sheldon, S., \& Byers, J. L. (2002). Conditions for classroom technology innovations. Teachers College Record, 104(3), 482-515.

\section{Copyrights}

Copyright for this article is retained by the author(s), with first publication rights granted to the journal.

This is an open-access article distributed under the terms and conditions of the Creative Commons Attribution license (http://creativecommons.org/licenses/by/3.0/). 